Available online on 15.11.2020 at http://jddtonline.info
Open Access to Pharmaceutical and Medical Research
unrestricted non-commercial use, provided the original work is properly cited

Open Access

Review Article

\title{
Zahar Mohra (Bezoar) an Alexipharmic Unani Mineral Drug: Review
}

\author{
Mustehasan ${ }^{*}$, Misbahuddin Azhar2, Sofia Naushin¹, Mahe Alam¹ \\ ${ }^{1}$ Central Council for Research in Unani Medicine, Janakpuri New Delhi, 110058 \\ ${ }^{2}$ Regional Research Institute of Unani Medicine, Aligarh, 202002
}

\begin{abstract}
Rhazes (855-925 AD) the great scholar of Unani System Medicine (USM), initially classified Materia Medica according to animal, mineral and plant origin. Zahar Mohra is a Greenish white, good-looking mineral stone with a slippery feel having a good smell and taste obtained from mines. In USM it is considered to be a universal antidote. The great Unani Scholar Yuhannā Māsawayh (777-857 AD), was one of the first physicians who mentioned the medicinal uses of Zahar Mohra. In Unani Medicine it is used to treat epidemic diseases such as Haiza (Cholera), Tawoon (Plague), as an antidote for different poisoning and to provide strength to vital organs. To check adulteration the quality standard of Zahar Mohra has been laid down. All the available information regarding this historically important stone has been compiled which will help the researcher to find a solution of pandemic disease in the current scenario.
\end{abstract}

Key words: Zahar Mohra, Unani Medicine, Fade Zahar Kani, Mineral Bezoar

Article Info: Received 04 Sep 2020; $\quad$ Review Completed 21 Oct 2020; $\quad$ Accepted 06 Nov 2020; $\quad$ Available online 15 Nov 2020

Cite this article as:

Mustehasan, Azhar M, Naushin S, Alam M, Zahar Mohra (Bezoar) an Alexipharmic Unani Mineral Drug: Review, Journal of Drug Delivery and Therapeutics. 2020; 10(6):236-238 http://dx.doi.org/10.22270/jddt.v10i6.4395

*Address for Correspondence:

Dr. Mustehasan, Research Officer (U) Scientist-II, Central Council for Research in Unani Medicine, 61-65 institutional Area, Opp D Block Janakpuri, New delhi-110058

\section{INTRODUCTION:}

The substances cause injury, disease or death of living tissues when swallowed, injected or inhaled may be called poison. In the primitive era the man differentiated the useful plants, minerals and animals from poisonous one either by trial and error or through folklore ${ }^{1}$. Rhazes (855-925 AD) the great scholar of Unani Medicine, initially classified Materia medica according to animal, mineral and plant origin $^{2}$. The substances with properties to reverse, counteract, treat or manage a poisoned state may be called antidote $^{3}$. Bezoar stone is considered to be an universal antidote of Unani Medicine. It is available as mineral or animal origin. The bezoar stone of mineral origin is popularly known as Zahar Mohra, whereas bezoar of animal origin is called Padezahar or Fade zahar or Bade zahar or Pade zahar Haiwani ${ }^{4}$.

\section{Material AND Methods:}

In the present review Unani classical literature was searched for its complete description viz. temperament, actions, therapeutic, and dosage uses etc. For quality standards and other aspects to prove the importance of Zahar Mohra computerized databases such as Medline, Pubmed, Ovid SP,
Google Scholar and Science-direct were searched. All the information on Zahar Mohra available in Urdu, Persian, Arabic and studies published abstract were included.

\section{Vernacular names ${ }^{4,6,8-20}$}

Arabic: Hajr-us-sum, Bad Zahr Kani, Hajrul-bahr English: Serpentine, Green Marble, Mineral Bezoar Hindi: Jahara moharā, Pedaru, bazaar Persian: Fad Zahar Madani Latin: Lapis bezorticum, Sanskrit: Naagpashad, Haritashm

\section{Description and History:}

ZaharMohra is a Greenish white, good-looking mineral stone with a slippery feel having a good smell and taste obtained from mines. Various coloured such as white, yellow, green, dusty, and abrasive are described in literature, however the pale stones with white and green hues are considered of good quality4 ${ }^{4}$. It is also known as Bezoar stone or Serpentine. The word "bezoar" is derived from Arabic word bad $z a h r$ and from Persian word pād-zahr $\mathrm{Pa}$ means protection and Zahr means poison, which literally means "antidote" 5. Due to its slippery feel and green patterned appearance like serpent (snake) it is referred as Serpentine6. 
The great Unani Scholar Yuhannā Māsawayh (777-857 AD), was one of the first physicians who mentioned the medicinal uses of Zahar Mohra. Abu al-Rayhan Muhammad ibn Ahmad al-Biruni (973-after 1050), author of Kitab al-Jamahir fi ma'rifat al-jawahir (Book on the Multiple Knowledge of Precious Stones) exclusively to gems, minerals, and metals. He quoted:

"As a matter of fact, this stone should have been the costliest among stones, for, whereas jewels are things of the body and adornment, and are of no use in body ailments, the bezoar stone guards the body and the soul and saves them from being harmed". 7

\section{Occurrence}

It is found in China, Khata (now part of China), Tibbet, and Iran (Qandhar, Khurasan). In India it is found in Ajmer and Kota Districts of Rajasthan. Zahar Mohra found in Khata is considered of best quality and is known as Zahar Mohra Khatai ${ }^{4,6,8-20 .}$.

\section{Temperament}

There is conflict in statement among Unani scholars for its temperament some says it is Hot and Dry $4,6,9,11,12,15,17,19,20$ some says it is Cold and Dry, ${ }^{4,9}$ while some says it is Moderate towards hotness ${ }^{4,8,16}$.

\section{Action}

Unani scholars mentioned it action as Muqawwi-e-Aza-eRaeesa (tonic for vital organs), Mufarreh (Exhilarant), Daf-eHumma wabaiya (Antipyretic for epidemic fevers), Daf-eamraz chasm (anti ophthalmic diseases), Daf-e-Tezabiyat (antacid), Tiryaq-e-samoom (Antidote), Muqawwi-e-bah (aphrodisiac) and Muqawwi-e-asab (Nervine tonic), Mohallil (anti-inflammatory) 4,6,8-20.

\section{Uses}

According to their action Unani scholars recommended Uses in Amraz wabaiya (epidemic disease) such as Haiza (Cholera), Tawoon (Plague), antidote for poisons and aqrab gazeeda (scorpion sting), Khafqan (palpitation), Qai wa ishal (vomiting and diarrhoea) Ashoob chasm (conjunctivitis), Hummiyat-e-wabaiya (epidemic fever), Humuzat-e-Meda (gastric acidity).

In cases of all disease conditions mentioned above, it is given after grounding with Arq Gulab or Araq Bed mushk orally. In case of scorpion stings and other insect bites, it is applied locally after grounding with Ara Gulab. Local application along with aab-e-kishneez sabz (coriander juice) is beneficial in hot inflammations $4,6,8-20$.

\section{Potent Action}

The potent action of Muqawwi-e-Aza-e-Raeesa (tonic for principal organs), Daf-e-Sumoom (antidote) 4,6,8-20.

\section{Dosage}

Unani scholars advocated for the use of powder and calx. For powder from its dose may be $1 \mathrm{gm}$ (powder) $4,6,8-20$ for calx it may be $125 \mathrm{mg}$ (calx) ${ }^{27}$.

\section{Elemental analysis/composition}

When we define serpentine in geological terms, it is a metamorphosed rock consisting of a group of minerals having magnesium, iron, nickel, aluminium, zinc, manganese, silicon, aluminium, or iron. Chemically it is Hydrous magnesium iron silicate with the formula (Mg,Fe,Ni, Mn, $\mathrm{Zn})_{2}$ $3(\mathrm{Si}, \mathrm{Al}, \mathrm{Fe})_{2} \mathrm{O}_{5}(\mathrm{OH}) 4^{21}$.

\section{Quality Standards of Zahar Mohra}

In order to check adulteration, the Scientists have laid down the quality standard of Zahar Mohra stone for medicinal use.

\section{Physical properties}

Blackish green in colour, Crystalline, coarse grained in nature, soapy feel greasy in lustre, translucent, perfect cleavage, conchoidal fracture, tough, hardness ranges 3.5-5, specific gravity $2.5-2.76$ optically bi-axial, negative, weakly birefringent with refractive index range 1.546-1.554.22

\section{Chemical Properties}

The sample gets decomposed and gives off a little water at around 500 degree, should contain not less than $30 \%$ magnesium oxide, $30 \%$ Silica $\left(\mathrm{SiO}_{2}\right), 5 \%$ Ferric oxide $\left(\mathrm{Fe}_{2} \mathrm{O}_{3}\right)$ and $5 \%$ calcium oxide $(\mathrm{CaO})$ when analysed by gravimetric method. Should not contain more than $2 \mathrm{ppm}$ of arsenic and 3 ppm of cadmium. May contain $0.15 \%$ Nickel within $\pm 20 \%$ of limits when analysed by Atomic Absorption Spectrophotometer 22 .

\section{Muzarrat (Adverse Action)}

According to Unani scholars the Zahar Mohra has no adverse reaction 4,6,8,10-20. However, some of the scholars are of the view that it can produce kidney stones if taken in excess amount ${ }^{9}$.

\section{Musleh (Corrective)}

Unani system of medicine also has a unique speciality of adding Corrective Drugs (Mușlih Adwiya) to counter the toxicity of the main drug. Since the drug is not having any adverse reaction the Unani Scholars have not mentioned any corrective for it $4,6,8,10-20$. The Scholar who says that it can produce urinary stone have mentioned Sharbat Bazoori as its corrective ${ }^{9}$.

\section{Badal (Substitute)}

Unani scholars also said that in case of non-availability of genuine medicine a substitute may be used. Most of the Unani scholars have mentioned Zamarrud and Zabarjad as its substitute $4,6,8-20$.

\section{Mashoor Murakkabat (Important Formulations)}

Some important classical Unani formulations in which Zahar Mohra is one of the ingredients mentioned in National Formulary of Unani Medicine are as follows:

Habbe Ambar Momiyaee, Habb-e-Zahar Mohra, Habb-eJawahir, Habb-e-Nishat, Habb-e-Tabasheer, Khamira Gaozaban Ambari Jawahar Wala, Kushta Zahar Mohra, Jawahir Mohra 23. Habb-e-Qabiz ${ }^{24}$. Habb-e-Jawahar Moallif, Habb-e-Jawahar Moallif Khas, Habb-e-Kafoor Marwareedi, Habb-e-Lulavi, Habb-e-Taoon Qawi, Habb-e-Taoon Jawhar Wali, Habb-e-Yaqoot ${ }^{25}$. Habb-e-Kafoor, Qurs Shifa Hindi26. Habb-e-Jawahar, Khamira Gaozaban Ambari Jawahar Wala, Khamira Marwareed Khas, Qurs Fizza, Kushta Zahar Mohra, Jawahar Mohra27. Habb-e-muqawwi Khas, Qalbeen, Ikseer-eAtfal, Yashabi, Khamira Zahar Mohra, Jawarish Amla Lulavi, Kushta Sadaf, Zehbi, Nawed-e-Nau'28.

\section{Conclusion:}

In Unani Medicine a quite number of mineral origins drugs are used to treat different ailments. Hajar ul Yahood is popular for treating urinary stones ${ }^{29}$. Kibreet is considered a good blood purifier ${ }^{30}$. The calx prepared from Abrak is beneficial to treat respiratory diseases ${ }^{31}$, while preparations of Samm ul Far are used to treat sexual disorders, skin disorders, anaemia and fevers ${ }^{32}$. Zahar Mohra is considered 
as an antidote for various poisoning since ancient times. Unani scholars have mentioned Zahar Mohra as antipyretic for epidemic fever, so it may be evaluated for its action in pandemic fever of COVID-19. It is one of the main ingredients of various important Unani formulations. Adulteration in mineral drugs is a big issue, for identification of good quality material standards have been laid down. Most of the Unani Scholars are of the view that Zahar Mohra does not have toxic effects. It is the need of the hour to evaluate its efficacy on epidemic diseases on scientific parameters. This review will help researchers for further studies of Zahar Mohra.

\section{References}

1. Khan AB, Tariq M, Afaq SM Asif M, "Poisons and antidotes in Unani System of Medicine" Indian J of History of Science, 1981; 16(1):51-63

2. Schuh CP. Mineralogy \& Crystallography: On the History of the Sciences from Beginning through 1919. Tucson Arizona, 2007. P.33-34.

3. Nikfar S, Khatibi M, Abdollahiasl A, Abdollahi M. "Cost and utilization study of antidotes: An Iranian experience, Int. J. Pharmacol. 2011; 7(1):46-49.

4. Ghani MN. Khazain-ul-Advia. Vol-IV, (urdu translation), Abdul Hamid Publishers and Printers Lahore, 1926. P.279-280.

5. https://www.etymonline.com/word/bezoar (accessed on 23.08.2020)

6. Ansari Y. Munafa ul Mufradat. Aijaz Publishing House Delhi, 2009. P.461.

7. Maria Do Sameiro Barroso, "The Bezoar Stone: A Princely Antidote, The TávoraSequeira Pinto Collection - Oporto": Acta Med-hist Adriat, 2014; 12(1):77-98

8. Ashraf M. Makhzan ul Mufradat (KhawasulAdvia) Ma Murakkabat. Aijaz Publishing House, Delhim 2011. P.140

9. Rafiquddin M. Kanzul Advia Mufrada. University publication unit, Sarfaraz house, AMU Aligarh, 1985. P.391.

10. Hakeem MA. Bustan-ul-Mufradat. Aijaz Publishing House Delhi, 2011. P.188.

11. Haleem MA. Mufradat-e-Azizi. CCRUM Publication New Delhi, 2009. P.28, 35,40,63.

12. Khan MA. Muheet-e-Azam. Vol-I, CCRUM Publication New Delhi. 2013. P.532-537.

13. Ibn Baitar ZU. Kitab-al-Jami-ul-Mufradat-al Adviawal Aghzia. Vol-I, (urdu translation), CCRUM Publication, New Delhi. 1985. P.200-202.

14. Kabiruddin M. Makhzan-ul-Mufradat. vol-I, National fine Printing Press, Hyderabad. 1955. P.321-322.

15. Ali SS. Unani Advia Mufrada. 10th Eds, National Council for Promotion of Urdu Language, New Delhi. 2004. P.304.

16. Lubhaya R. Bayan ul Advia. Vol-I, Idara Matbul Sulemani Lahore. 2001. P.267-268.
17. Singh D. Unani Dravyaguna Vigyan. Nirnay Sagar press Mumbai. 1949. P.237-238.

18. Mustehasan, Ali A. Advia Madania. Aijaz Publishing House Delhi. 2004. P.53-54.

19. Tariq NA. Taj-ul-Mufradat (Khawas-ul-Advia). Idara Kitaab-ulShifa, New Delhi. 2004. P.411-412.

20. Nabi G. Makhzanul Mufradat wa Murakkabat Maroof Khawasul Advia, CCRUM Publication New Delhi, 2007. P.138139.

21. https://geology.com/minerals/serpentine.shtml 19.08.2020.

22. Anonymous. The Ayurvedic Pharmacopoeia of India. Part-I vol-VII Minerals and metals. Department of Ayurveda, Yoga \& Naturopathy, Unani, Siddha and Homoeopathy (AYUSH), Ministry of Health \& Family Welfare, Government of India. 2008. P.15-16.

23. Anonymous. National Formulary of Unani Medicine. Part-I. Department of Ayurveda, Yoga \& Naturopathy, Unani, Siddha and Homoeopathy (AYUSH), Ministry of Health \& Family Welfare, Government of India. 2006. P.10,20,28,36,35,110, $113,231$.

24. Anonymous. National Formulary of Unani Medicine. Part-II. Department of Ayurveda, Yoga \& Naturopathy, Unani, Siddha and Homoeopathy (AYUSH), Ministry of Health \& Family Welfare, Government of India. 2007. P.20.

25. Anonymous. National Formulary of Unani Medicine. Part-III, Department of Ayurveda, Yoga \& Naturopathy, Unani, Siddha and Homoeopathy (AYUSH), Ministry of Health \& Family Welfare, Government of India. 2001. P.19,20,22,27,42,43,46.

26. Anonymous. National Formulary of Unani Medicine. Part-IV, Department of Ayurveda, Yoga \& Naturopathy, Unani, Siddha and Homoeopathy (AYUSH), Ministry of Health \& Family Welfare, Government of India. 2006. P.15,42.

27. Anonymous. National Formulary of Unani Medicine. Part-V. Department of Ayurveda, Yoga \& Naturopathy, Unani, Siddha and Homoeopathy (AYUSH), Ministry of Health \& Family Welfare, Government of India. 2008. P.10,21,59,78,81,149.

28. Anonymous. National Formulary of Unani Medicine. Part-VI. Department of Ayurveda, Yoga \& Naturopathy, Unani, Siddha and Homoeopathy (AYUSH), Ministry of Health \& Family Welfare, Government of India. 2011. P.18,24,26,27,56,58,59, 66.

29. Mustehasan, Azhar MU, "Hajar ul Yahood (Jew's Stone) AntiUrolithiatic Unani Mineral Drug-Review" World Journal of Pharmaceutical Research, 2020; 9(6):1127-1133.

30. Mustehasan, Azhar MU, Naushin S, "Kibreet (Sulphur) A Unani Mineral Drug- Review, "IJSRBS, 2020; 7(3):121-126,

31. Mustehasan, Azhar MU, Naushin S, "Historical Ethnopharmacological Review of a Unani Mineral Drug-Samm al-Far (Arsenic Trioxide)" HJUM, 2020; 15(2):21-32.

32. Mustehasan, Azhar MU, "Abrak (Mica) And Its Unani Formulations-Review” WJPR, 2020; 9(8):2475-2484. 